\title{
Enrichment of probiotic ice cream with different dietary fibers: Structural characteristics and culture viability
}

\author{
A. S. Akalın, ${ }^{1}$ H. Kesenkas, N. Dinkci, G. Unal, E. Ozer, and O. Kınık \\ Department of Dairy Technology, Faculty of Agriculture, University of Ege, 35100 Bornova, Izmir, Turkey
}

\begin{abstract}
This study evaluated the effect of 5 dietary fibers (apple, orange, oat, bamboo, and wheat) on the physicochemical, rheological, and textural characteristics; sensory properties; and culture viability of probiotic ice cream stored at $-18^{\circ} \mathrm{C}$ for $180 \mathrm{~d}$. The presence of orange and apple fibers increased the titratable acidity, decreased the lightness (color) value of the ice creams, and enhanced the red and yellow coloration. Compared with the control sample, the consistency indices and apparent viscosities of the experimental samples increased with the addition of all dietary fibers except oat fiber. The highest viscosity was obtained in the sample fortified with apple fiber, whereas the ice cream containing orange fiber showed the highest hardness after d 60 of storage. The addition of orange and apple fibers significantly increased melting resistance; however, panelists did not generally like these samples in terms of taste-flavor. All ice creams had viable counts of Lactobacillus acidophilus of $\geq 7 \mathrm{log} \mathrm{cfu} / \mathrm{g}$ during storage except the samples with orange and bamboo fiber. Bifidobacterium lactis counts were also found to be $>6$ $\log \mathrm{cfu} / \mathrm{g}$ in those samples until d 150 of storage.
\end{abstract}

Key words: probiotic ice cream, dietary fiber, texture, probiotic viability

\section{INTRODUCTION}

Ice cream is a complex multiphase system that consists of dispersed air cells, partially coalesced fat globules, ice crystals, and a continuous aqueous phase in which dissolved (lactose and mineral salts) and suspended (polysaccharides and proteins) substances are dispersed (Marshall et al., 2003). Ice cream has good potential for use as a probiotic vehicle because of its composition as well as its pleasant taste and attractive texture. Furthermore, probiotics are able to survive

Received July 10, 2017.

Accepted September 9, 2017.

${ }^{1}$ Corresponding author: sibel.akalın@ege.edu.tr over long storage periods in frozen systems such as ice cream matrix that includes nutritive constituents such as milk proteins, fat, and lactose (Cruz et al., 2009).

Recently, new ice cream formulations have been developed with improved nutritional, sensory, and textural properties. The addition of dietary fibers can improve the textural characteristics of food depending on their water-binding and gel-forming ability, as well as texturizing and thickening effects (Staffolo et al., 2004). According to the National Academies of Science (Washington, DC), the average daily consumption of dietary fiber is significantly lower than the adequate intakes of 38 and $25 \mathrm{~g}$ for men and women, respectively (Sah et al., 2016). Therefore, dietary fiber has been included in various food formulations to improve health effects, such as by serving as prebiotic substance for probiotic bacteria, lowering cholesterol, and reducing blood glucose responses and providing laxation effects.

In some studies, dietary fiber has been investigated as a texturizing agent in the manufacture of ice cream. The use of a combination of citrus fiber and stabilizer/ emulsifier was reported to have a desirable effect on the physical, chemical, and sensory properties of ice cream (Dervisoglu and Yazıcı, 2006). Soukoulis et al. (2009) investigated the effect of 4 different dietary fiber sources on rheological properties and ice crystallization and glass transition phenomena in ice cream mixes. The dietary fibers were proposed to have potential use in controlling crystallization and recrystallization in frozen dairy products. Textural and sensory characteristics of lemon ice cream have been enhanced with orange fiber (Crizel et al., 2014), and the effect of rice flour in vanilla ice cream (Cody et al., 2007) has been studied.

However, no detailed research has examined both the textural and prebiotic effects of dietary fibers in probiotic ice cream. In this respect, the effect of inulin has been investigated. Di Criscio et al. (2010) reported that inulin increased the total counts of lactic acid bacteria (Lactobacillus casei and Lactobacillus rhamnosus) in probiotic ice cream, whereas a similar prebiotic effect on Lactobacillus acidophilus and Bifidobacterium 
animalis Bb12 was not found in another study (Akalın and Erişir, 2008).

The aim of this study was to evaluate the influence of 5 different dietary fibers (wheat, oat, bamboo, apple, and orange) on the physicochemical, rheological, and textural characteristics, probiotic culture survival, and sensory properties of probiotic ice cream.

\section{MATERIALS AND METHODS}

\section{Manufacture of Probiotic Ice Cream}

The ice creams were produced in the pilot plant of the Dairy Technology Department in the Agricultural Faculty of Ege University (Izmir, Turkey). The formulation of ice cream mix consisted of $6 \%$ milk fat, $12 \%$ nonfat milk solids, $16 \%$ sucrose, $0.60 \%$ stabilizer/emulsifier, and $2 \%$ dietary fiber. The ingredients used in the ice cream manufacture were as follows: cow milk $(3.5 \%$ milk fat, from Menemen Research Farm, Agricultural Faculty, Ege University), pasteurized cream (35\% milk fat), and nonfat milk powder (Pinar Dairy Industry, Izmir, Turkey); freeze-dried DVS (direct vat set) starter cultures of Lactobacillus acidophilus and Bifidobacterium lactis Bb12 (Chr. Hansen, Horshølm, Denmark); sucrose (purchased in a local store); stabilizer/emulsifier mixture containing mono- and diglycerides of fatty acids, locust bean gum, guar gum, and carrageenan (Cremodan SE 709 VEG, Danisco AS, Copenhagen, Denmark); and dietary fibers Jelucel wheat fiber 30 (0.5\% soluble fiber, $97.5 \%$ insoluble fiber), Jelucel oat fiber $(0.5 \%$ soluble fiber, $97.3 \%$ insoluble fiber), Jelucel bamboo fiber 30 (0.5\% soluble fiber, $98.0 \%$ insoluble fiber) (all from Jelu, Rosenberg, Germany), Vitacel 401-30 apple fiber (10\% soluble fiber, $45 \%$ insoluble fiber), and Vitacel 405 orange fiber (18\% soluble fiber, $24 \%$ insoluble fiber) (both from Vitacel, Rosenberg, Germany).

An 11-kg batch of ice cream mix was prepared for each processing group. Raw cow milk and cream were mixed in a stainless steel milk can, and the temperature was increased to $45^{\circ} \mathrm{C}$. Dietary fibers were added to the blend of skim milk powder, sugar, and stabilizer/ emulsifier mixture except in the control sample. The mixtures were pasteurized at $78^{\circ} \mathrm{C}$ for 30 min with constant stirring and then rapidly cooled to $40^{\circ} \mathrm{C}$. The starter culture of L. acidophilus and B. lactis Bb12 was added to all mixes to achieve approximately $10^{8} \mathrm{cfu} / \mathrm{g}$, mixed well, and fermented for approximately $3.5 \mathrm{~h}$ at $40^{\circ} \mathrm{C}$ until the $\mathrm{pH}$ of 5.5 was reached.

The fermented mixes were then cooled to $5^{\circ} \mathrm{C}$ in an ice bath and aged at $4^{\circ} \mathrm{C}$ for $20 \mathrm{~h}$. Then, the mixes of $6.5 \mathrm{~kg}$ were frozen in a batch freezer (4-L capacity,
Uğur, Nazilli, Turkey) for $20 \mathrm{~min}$. At a drawing temperature of $-6.0^{\circ} \mathrm{C}$, extruded ice creams were packaged into $100-\mathrm{mL}$ plastic containers and stored at $-18^{\circ} \mathrm{C}$ for $6 \mathrm{mo}$.

\section{Physicochemical Properties}

Ice cream samples were analyzed for total solids (gravimetric method), fat (Gerber method), protein (Kjeldahl method), titratable acidity, and $\mathrm{pH}$ (Akalın and Erişir, 2008). The overrun values were determined using the following formula: Overrun $(\%)=$ (weight of ice cream mix - weight of ice cream)/(weight of ice cream) $\times 100$ (Marshall et al., 2003). The color of the ice cream samples was quantitatively determined using a Minolta CR-400 colorimeter (Minolta, Osaka, Japan) and defined using the $\mathrm{L}^{*} \mathrm{a}^{*} \mathrm{~b}^{*}$ system, where $\mathrm{L}^{*}$ $=$ lightness, $\mathrm{a}^{*}=$ red-green color, and $\mathrm{b}^{*}=$ yellow-blue color.

\section{Rheological Measurements}

The rheological behavior of the aged ice cream mixes was determined by the modified method of Riener et al. (2010). Steady shear rheological measurements of ice cream mixes were performed at $25^{\circ} \mathrm{C}$ after aging using a rotational viscometer (cone $\mathrm{C} 60 / 1 \mathrm{Ti}$, plate cover MPC60/s, Haake Mars, Karsruhe, Germany) equipped with a cone-and-plate geometry (40 $\mathrm{mm}$ diameter). A shear stress ramp (10 to $300 \mathrm{~s}^{-1}$ ) was applied to the ice cream mixes. The data obtained were adjusted to a

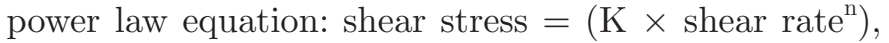
where $\mathrm{K}$ is the consistency index, and $\mathrm{n}$ is the flow behavior index. The apparent viscosity of the samples was measured at a constant shear rate of $110 \mathrm{~s}^{-1}$.

\section{Light Microscopy}

The microstructure of the ice cream mixes was visualized at $40 \times$ magnification using a digital camera (Coolpix 4500, Nikon, Tokyo, Japan) attached to a light microscope (Olympus, Tokyo, Japan). Image processing was carried out using Paint Shop Pro software (Jasc Software, Minneapolis, MN).

\section{Texture Analysis}

Analysis of hardness was conducted using a Brookfield Texture Analyzer (CT-3 4500, Brookfield USA, Middleboro, MA). The samples were kept in plastic containers (65 $\mathrm{mm}$ in diameter, $35 \mathrm{~mm}$ long) and stored at $-20^{\circ} \mathrm{C}$ until the analysis (Brookfield Engineering Laboratories, 2014). Compression analyses were carried 
Table 1. Chemical composition (g/100 g; means $\pm \mathrm{SD}$ ) of probiotic ice cream samples $(\mathrm{n}=3)$

\begin{tabular}{lccc}
\hline Treatment $^{1}$ & Total solids & Protein & Fat \\
\hline $\mathrm{C}$ & $34.64 \pm 0.05^{\mathrm{b}}$ & $3.62 \pm 0.42^{\mathrm{a}}$ & $6.5 \pm 0.00^{\mathrm{a}}$ \\
$\mathrm{A}$ & $36.73 \pm 0.19^{\mathrm{a}}$ & $4.05 \pm 0.07^{\mathrm{a}}$ & $6.0 \pm 0.00^{\mathrm{b}}$ \\
OR & $37.31 \pm 0.24^{\mathrm{a}}$ & $4.02 \pm 0.02^{\mathrm{a}}$ & $6.0 \pm 0.00^{\mathrm{b}}$ \\
$\mathrm{OA}$ & $37.52 \pm 0.65^{\mathrm{a}}$ & $3.76 \pm 0.23^{\mathrm{a}}$ & $6.0 \pm 0.00^{\mathrm{b}}$ \\
$\mathrm{B}$ & $36.80 \pm 0.66^{\mathrm{a}}$ & $3.76 \pm 0.34^{\mathrm{a}}$ & $6.0 \pm 0.00^{\mathrm{b}}$ \\
$\mathrm{W}$ & $36.77 \pm 0.98^{\mathrm{a}}$ & $3.76 \pm 0.04^{\mathrm{a}}$ & $6.0 \pm 0.00^{\mathrm{b}}$ \\
\hline
\end{tabular}

${ }^{a, b}$ Means with different letters in the same column are significantly different $(P<0.05)$.

${ }^{1}$ Treatments: $\mathrm{C}=$ control probiotic ice cream, $\mathrm{A}=$ probiotic ice cream with $2 \%$ apple fiber, $\mathrm{OR}=$ probiotic ice cream with $2 \%$ orange fiber, $\mathrm{OA}=$ probiotic ice cream with $2 \%$ oat fiber, $\mathrm{B}=$ probiotic ice cream with $2 \%$ bamboo fiber, $\mathrm{W}=$ probiotic ice cream with $2 \%$ wheat fiber.

out at $-10^{\circ} \mathrm{C} \pm 1{ }^{\circ} \mathrm{C}$, using a 5 -mm cylindrical probe (TA 35). The penetration depth at the geometrical center of the samples was $20.0 \mathrm{~mm}$, the trigger load was $5.0 \mathrm{~g}$, and the test speed was $2.0 \mathrm{~mm} / \mathrm{s}$. The results were calculated with Texture Pro CT software (Brookfield USA). Hardness was determined as the maximum force on the graph during penetration.

\section{Melting Rate}

Melting rate was evaluated on ice cream samples stored at $-18^{\circ} \mathrm{C}$ for 6 mo. Melting rate was determined by carefully cutting the plastic cups from the 100 -g ice cream samples, placing the ice cream onto a 1-mm stainless steel mesh over a cup and weighing the amount of ice cream that drained into the cup over a 90-min period at $25^{\circ} \mathrm{C}$. The measurements were done in triplicate. Melting rate was measured as the weight of drip versus time (Akalın et al., 2008).

\section{Enumeration of Probiotic Bacteria}

The colony counts of Lb. acidophilus and B. lactis were enumerated in each ice cream sample using de Man, Rogosa, and Sharpe (MRS)-sorbitol and MRSNNLP (where NNLP = nalidixic acid, neomycin sulfate, lithium chloride, and paromomycin sulfate) agar, respectively (Tharmaraj and Shah, 2003). The inoculated plates were incubated anaerobically at $37^{\circ} \mathrm{C}$ for 72 $\mathrm{h}$ using Anaerocult A (Merck, Darmstadt, Germany) in anaerobic jars.

\section{Sensory Evaluation}

Sensory evaluation was carried out in ice cream samples during $6 \mathrm{mo}$ of storage at $-18^{\circ} \mathrm{C}$ (Homayouni et al., 2008). Sensory analysis was performed by a group of 8 panelists who were experienced academicians from the Department of Dairy Technology (Ege University).
The ice cream samples $(50 \mathrm{~g})$ were coded with a 3 -digit random number and organoleptically assessed by the panelists under fluorescent white light using a sensory rating scale of 1 to 10 for taste-flavor, and 1 to 5 for texture, and 1 to 5 for color-appearance.

\section{Statistical Analysis}

The effects of different dietary fibers and ripening on the characteristics of the ice creams were determined by an ANOVA, and the mean differences were analyzed using Duncan's multiple range test using SAS software (version 8; SAS Institute Inc., Cary, NC).

\section{RESULTS AND DISCUSSION}

\section{Physicochemical Properties}

The contents of total solids, protein, and fat are shown in Table 1. As expected, the incorporation of dietary fiber into the ice cream mix increased the total solids content of ice cream.

The presence of different dietary fibers and the storage time significantly affected the lactic acid contents of the ice cream samples (Table 2). The titratable acidity results showed that fortification with orange, apple, and bamboo fibers increased the acidity of the samples compared with the control and other samples $(P<0.05)$. Generally, the lactic acid content $(\%)$ of probiotic ice cream samples changed in the order of orange $>$ apple $>$ bamboo $>$ wheat $>$ control $>$ oat during storage. The addition of citrus fiber and some phenolic substances caused an increase in acidity $(P<$ $0.05)$ due to the acidic nature of phenolic substances (Dervisoglu and Yazıcı, 2006; Sagdic et al., 2011). The acidity values fluctuated throughout storage in control and experimental ice creams.

We detected no significant differences in color parameters between probiotic ice creams except for the samples fortified with orange and apple fibers (Table $3)$. The addition of orange and apple fibers decreased $(P<0.05)$ the lightness $\left(\mathrm{L}^{*}\right)$ value, whereas the ice cream samples with wheat, oat, and bamboo did not significantly differ from the control sample in terms of that $\mathrm{L}^{*}$. The presence of apple and orange fibers also enhanced the red and yellow colors of the ice cream, resulting in an increase in the values of $a^{*}$ and $b^{*}$, respectively. Similar findings were obtained by the addition of apple and orange fibers to yogurt and ice cream milk base. The use of apple fiber in yogurt manufacture caused a decrease in $\mathrm{L}^{*}$ value and an increase in $\mathrm{a}^{*}$ and b* values (Staffolo et al., 2004; Damian, 2013). Similarly, ice cream samples supplemented with orange fiber (Crizel et al., 2014) or citrus fiber (Dervisoglu 
Table 2. Lactic acid contents (g/100 g; means $\pm \mathrm{SD})$ of probiotic ice creams during storage $(\mathrm{n}=3)$

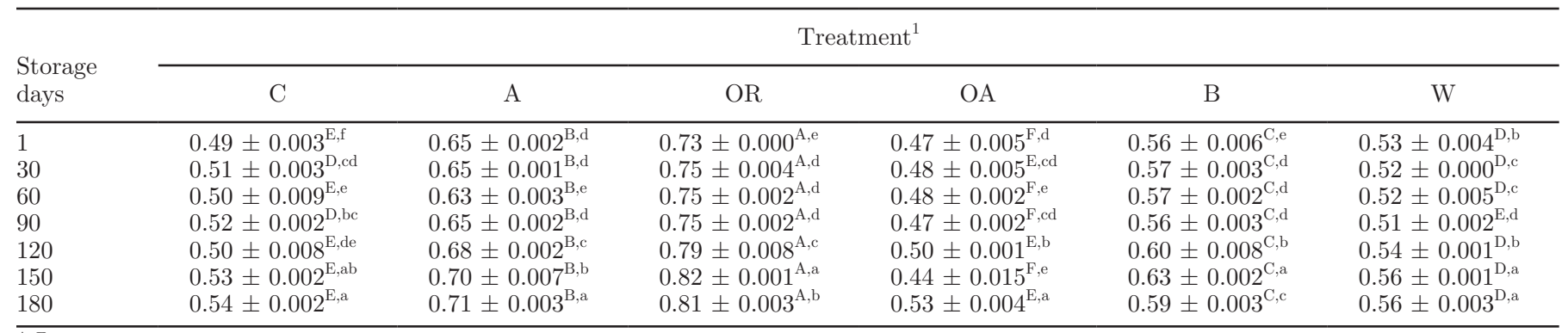

${ }_{\mathrm{A}-\mathrm{F}}$ Means with different uppercase letters in the same row are significantly different $(P<0.05)$.

${ }^{\mathrm{a}-\mathrm{f}}$ Means with different lowercase letters in the same column are significantly different $(P<0.05)$.

${ }^{1}$ Treatments: $\mathrm{C}=$ control probiotic ice cream, $\mathrm{A}=$ probiotic ice cream with $2 \%$ apple fiber, OR $=$ probiotic ice cream with $2 \%$ orange fiber, $\mathrm{OA}=$ probiotic ice cream with $2 \%$ oat fiber, $\mathrm{B}=$ probiotic ice cream with $2 \%$ bamboo fiber, $\mathrm{W}=$ probiotic ice cream with $2 \%$ wheat fiber.

and Yazıc1, 2006) had significantly lower $\mathrm{L}^{*}$ values and higher $\mathrm{a}^{*}$ and $\mathrm{b}^{*}$ coordinate values, demonstrating that the addition of these fibers resulted in a product that was less bright and more red and yellow than the others.

Overrun is associated with the amount of air incorporated during the manufacture of ice cream (Cruz et al., 2009). Figure 1 illustrates the overrun index values of ice cream samples. The overrun ratios of the samples were low, ranging from 25.55 to $30.60 \%$, similar to the findings of Crizel et al. (2014) and Di Criscio et al. (2010). In the batch-type freezing system, air is incorporated into the mix at atmospheric pressure. The low overrun values may have occurred due to the batch freezing, and the lack of homogenization is a limitation of this study. The addition of dietary fiber increased the overrun of the experimental ice cream samples compared with the control except for the sample containing bamboo fiber. Supplementation with apple, orange, or wheat fiber increased the incorporation of air into ice cream $(P<0.05)$. Higher overrun values of ice creams containing these fibers could be attributed to their

Table 3. Color parameters ${ }^{1}$ (means $\pm \mathrm{SD}$ ) of probiotic ice-cream samples $(\mathrm{n}=3)$

\begin{tabular}{lcrr}
\hline Treatment $^{2}$ & \multicolumn{1}{c}{$\mathrm{L}^{*}$} & $\mathrm{a}^{*}$ & $\mathrm{~b}^{*}$ \\
\hline $\mathrm{C}$ & $90.46 \pm 0.10^{\mathrm{a}}$ & $-3.05 \pm 0.06^{\mathrm{c}}$ & $13.27 \pm 0.82^{\mathrm{b}}$ \\
$\mathrm{A}$ & $77.29 \pm 1.32^{\mathrm{c}}$ & $4.00 \pm 0.02^{\mathrm{a}}$ & $22.04 \pm 0.34^{\mathrm{a}}$ \\
OR & $85.40 \pm 2.39^{\mathrm{b}}$ & $-1.30 \pm 0.10^{\mathrm{b}}$ & $21.62 \pm 0.73^{\mathrm{a}}$ \\
$\mathrm{OA}$ & $89.76 \pm 1.20^{\mathrm{a}}$ & $-2.60 \pm 0.18^{\mathrm{c}}$ & $14.56 \pm 1.44^{\mathrm{b}}$ \\
$\mathrm{B}$ & $90.90 \pm 0.08^{\mathrm{a}}$ & $-2.55 \pm 0.51^{\mathrm{c}}$ & $14.07 \pm 0.17^{\mathrm{b}}$ \\
W & $88.76 \pm 0.85^{\mathrm{a}}$ & $-2.93 \pm 0.06^{\mathrm{c}}$ & $14.16 \pm 0.50^{\mathrm{b}}$ \\
\hline
\end{tabular}

${ }^{\mathrm{a}-\mathrm{C}}$ Means with different letters in the same column are significantly different $(P<0.05)$.

${ }^{1} \mathrm{~L}^{*}=$ lightness, $\mathrm{a}^{*}=$ red-green color, $\mathrm{b}^{*}=$ yellow-blue color.

${ }^{2}$ Treatments: $\mathrm{C}=$ control probiotic ice cream, $\mathrm{A}=$ probiotic ice cream with $2 \%$ apple fiber, $\mathrm{OR}=$ probiotic ice cream with $2 \%$ orange fiber, $\mathrm{OA}=$ probiotic ice cream with $2 \%$ oat fiber, $\mathrm{B}=$ probiotic ice cream with $2 \%$ bamboo fiber, $\mathrm{W}=$ probiotic ice cream with $2 \%$ wheat fiber. rheological properties. BahramParvar and Goff (2013) reported the capability of dashers of the batch freezer to incorporate more air into samples with higher viscosity. Akalın et al. (2008) also reported a positive relation between high overrun and high viscosity in ice cream. In contrast to our results, addition of orange fiber as a fat replacer caused significantly lower overrun values in ice cream compared with the control sample, possibly because of the lower milk fat content in the experimental samples (Crizel et al., 2014).

\section{Rheological Parameters}

The apparent viscosity, consistency index $(\mathrm{K})$, and flow behavior index (n) of the samples are given in Table 4. Flow behavior index values indicated that all

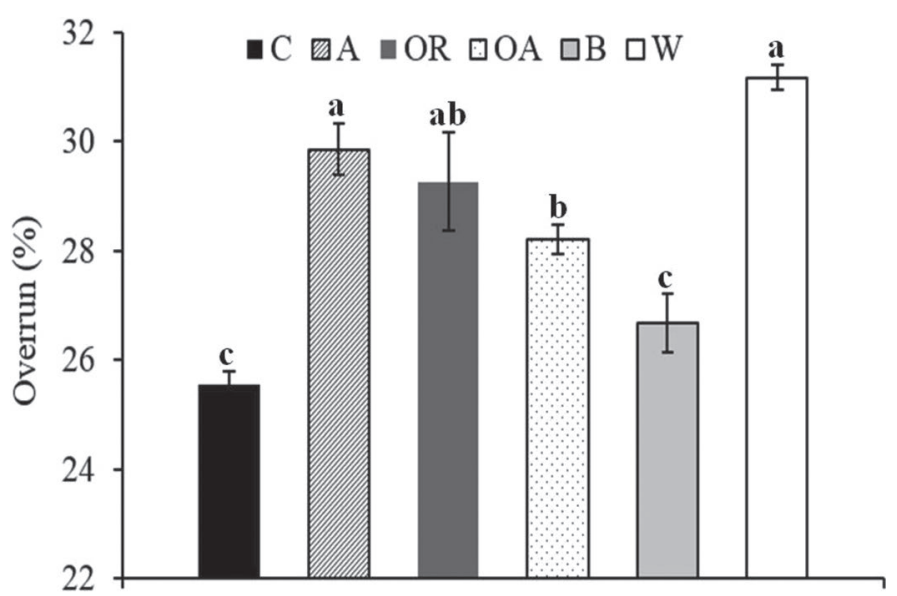

Figure 1. Overrun values of probiotic ice creams (mean $\pm \mathrm{SD} ; \mathrm{n}$ $=3) . \mathrm{C}=$ control probiotic ice cream, $\mathrm{A}=$ probiotic ice cream with $2 \%$ apple fiber, $\mathrm{OR}=$ probiotic ice cream with $2 \%$ orange fiber, OA $=$ probiotic ice cream with $2 \%$ oat fiber, $\mathrm{B}=$ probiotic ice cream with $2 \%$ bamboo fiber, $\mathrm{W}=$ probiotic ice cream with $2 \%$ wheat fiber. Bars with different letters $(\mathrm{a}, \mathrm{b}, \mathrm{c})$ are significantly different $(P<0.05)$. 
Table 4. Rheological parameters (means $\pm \mathrm{SD})$ of probiotic ice cream mixes after aging at $4^{\circ} \mathrm{C}$ for $20 \mathrm{~h}(\mathrm{n}=3)$

\begin{tabular}{lccc}
\hline Treatment $^{1}$ & $\begin{array}{c}\text { Apparent viscosity } \\
(\mathrm{Pa} \cdot \mathrm{s})\end{array}$ & $\begin{array}{c}\text { Consistency index } \\
\mathrm{K}\left(\mathrm{Pa} \cdot \mathrm{s}^{\mathrm{n}}\right)\end{array}$ & $\begin{array}{c}\text { Flow behavior } \\
\text { index, } \mathrm{n}\end{array}$ \\
\hline $\mathrm{C}$ & $0.042 \pm 0.001^{\mathrm{d}}$ & $3.346 \pm 0.05^{\mathrm{c}}$ & $0.155 \pm 0.002^{\mathrm{a}}$ \\
$\mathrm{A}$ & $0.133 \pm 0.006^{\mathrm{a}}$ & $10.439 \pm 0.391^{\mathrm{a}}$ & $0.160 \pm 0.002^{\mathrm{a}}$ \\
$\mathrm{OR}$ & $0.120 \pm 0.000^{\mathrm{b}}$ & $9.818 \pm 0.096^{\mathrm{a}}$ & $0.138 \pm 0.006^{\mathrm{bc}}$ \\
$\mathrm{OA}$ & $0.043 \pm 0.002^{\mathrm{d}}$ & $3.481 \pm 0.153^{\mathrm{c}}$ & $0.142 \pm 0.002^{\mathrm{b}}$ \\
$\mathrm{B}$ & $0.071 \pm 0.002^{\mathrm{c}}$ & $5.973 \pm 0.233^{\mathrm{b}}$ & $0.131 \pm 0.000^{\mathrm{c}}$ \\
$\mathrm{W}$ & $0.082 \pm 0.001^{\mathrm{c}}$ & $6.668 \pm 0.769^{\mathrm{b}}$ & $0.142 \pm 0.002^{\mathrm{b}}$ \\
\hline
\end{tabular}

${ }^{\mathrm{a}-\mathrm{d}}$ Means with different letters in the same column are significantly different $(P<0.05)$.

${ }^{1}$ Treatments: $\mathrm{C}=$ control probiotic ice cream, $\mathrm{A}=$ probiotic ice cream with $2 \%$ apple fiber, $\mathrm{OR}=$ probiotic ice cream with $2 \%$ orange fiber, $\mathrm{OA}=$ probiotic ice cream with $2 \%$ oat fiber, $\mathrm{B}=$ probiotic ice cream with $2 \%$ bamboo fiber, $\mathrm{W}=$ probiotic ice cream with $2 \%$ wheat fiber.

${ }^{2}$ Measured at $110 \mathrm{~s}^{-1}$.

samples showed non-Newtonian pseudoplastic behavior (because $\mathrm{n}<1$ ). The addition of all dietary fibers except apple into ice cream mix increased pseudoplasticity compared with that of the control sample, possibly because of soluble matter content.

As can be seen from Table 4, the highest consistency indices were seen in ice cream mixes fortified with apple and orange fibers $(P<0.05)$. Apparent viscosity, which is proportional to the consistency index, was also higher in the samples with apple and orange fiber than in the control and other ice creams. In addition, the presence of wheat and bamboo fibers increased these rheological parameters compared with the control sample $(P<$ 0.05). Soukoulis et al. (2009) reported that the increase in the viscosity of fiber-enriched ice cream mixes was attributed to the synergistic effect of soluble matter and insoluble fiber. The increase in viscosity and consistency indices of the samples containing wheat and bamboo fibers was likely a result of the high water retention of insoluble materials due to their low soluble matter content. On the other hand, apple and orange fibers led to a stronger effect on the increase of these parameters, probably because of the ability of their soluble and insoluble matters to bind water. Citrus and apple fibers are good sources of fiber with well-balanced soluble and insoluble fractions, as well as rich pectin content in the soluble material. The significant content of pectin, which is known for its gel-forming ability, in apple fiber explain why the ice cream mixes prepared with apple fiber had the highest viscosity $(P<0.05)$. Furthermore, the higher acidity of the samples containing apple and orange fibers could lead to an increase in heat denaturation of whey proteins, improving the water-binding capacity of the ice cream mix. Dimitreli et al. (2013) reported that denatured whey proteins resulted in higher values of apparent viscosity and consistency index values in kefir.

Similar findings were determined in ice cream mixes enriched with apple, wheat, and oat fibers by Soukoulis et al. (2009). However, oat fiber did not show any significant effect on the apparent viscosity and consistency index values of our ice cream mixes. This may have been caused by the difference in fiber compositions and the ratio of insoluble to soluble dietary fiber, which is higher in wheat fiber than in oat fiber (Pavlovich-Abril et al., 2012). Accordingly, Rodehutscord et al. (2016) reported that the extract viscosity of wheat fibers was found to be higher than that of oat fibers.

Figure 2 shows the microstructure of ice cream mixes prepared with different dietary fibers. The hydrated oat, wheat, and bamboo fibers can be easily seen compared with the serum area of the control sample, but only wheat fiber led to an increase in viscosity $(P<$ 0.05 ; Table 4). The microstructure of the ice cream mixes with apple and orange fiber was different from the other fiber-added samples because of their natural grainy morphology. However, a significant increase in viscosity was obtained in these samples $(P<0.05)$. Soukoulis et al. (2009) reported that the existence of grainy materials does not induce viscosity change; thus, that change may result from the presence of pectin.

\section{Hardness}

The hardness values of ice cream samples are shown in Table 5 . We detected no differences between samples on d 1 of storage $(P>0.05)$. Hardness values increased during storage for all samples except that supplemented with bamboo fiber. Supplementation with bamboo fiber led to the need for higher force to penetrate the ice cream (hardness) on d 30 compared with other samples $(P<0.05)$. This could result from the low overrun value of ice cream with bamboo fiber. However, the highest values of hardness were determined in samples supplemented with orange fiber between d 60 and 180 $(P<0.05)$. According to the general means, the highest hardness value $(1,125.76 \mathrm{~g})$ was determined in samples with orange fiber added, followed by those with wheat 

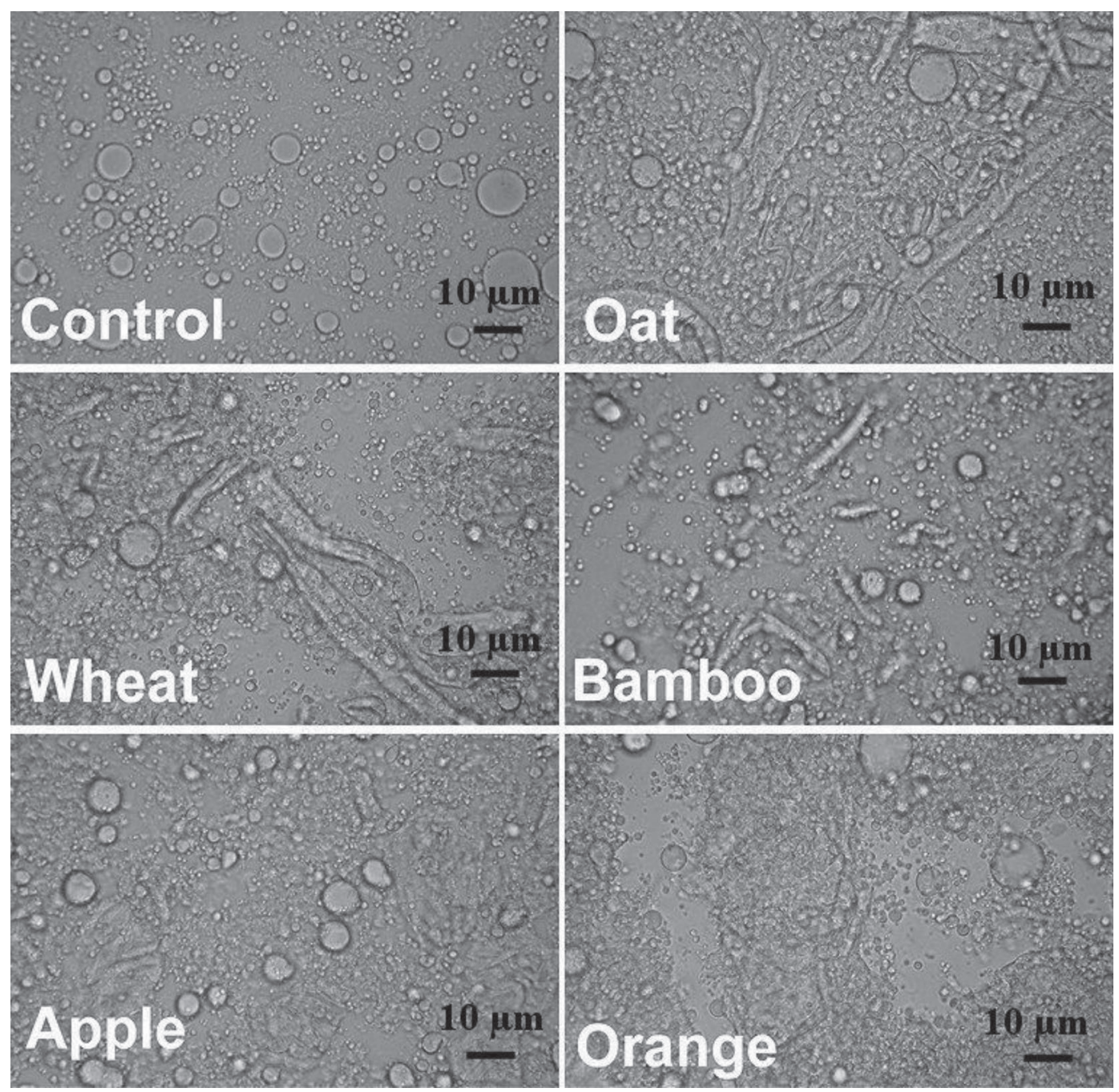

Figure 2. Light micrographs of aged ice cream mixes without (control) or with different dietary fibers.

fiber added (855.56 g; $P<0.05)$, which were significantly higher than those found in the control and the other experimental ice creams. This effect can be attributed to the gelling properties of orange fiber, which improved water-holding capacity, resulting in decreased rates of ice crystallization (El-Nagar et al., 2002). The ability of dietary fibers to bind water molecules and form a particle gel network can improve the firmness of a product (Akalın et al., 2008). Similar findings were reported by Crizel et al. (2014), who found that adding orange fiber caused a significant increase in ice cream hardness, which was more than 3 times that of the control sample.

The function of hydrocolloids in improving viscosity and decreasing molecular mobility has been correlated with control of ice crystal growth (BahramParvar and Tehrani, 2011). Any differences in hardness may be related to changes in freezing points because of the composition of the fiber or the concentration of soluble fibers.

According to Soukoulis et al. (2009), the type of fiber used in ice cream manufacture significantly affects the freezing point temperatures, as well as the temperature of bulk ice formation. Soukoulis et al. (2009) reported that the addition of wheat fiber resulted in a significant decrease in freezing point temperature, whereas addition of apple fiber led to a slight increase in freezing point. These differences were attributed to the serum composition enriched in high-molecular-weight biopolymers or high-molecular-weight polysaccharides in the case of wheat or apple fiber addition, respectively. In addition, addition of apple fiber led to a significant decrease in ice content and percentage of frozen water, whereas the addition of wheat fiber resulted in a signifi- 


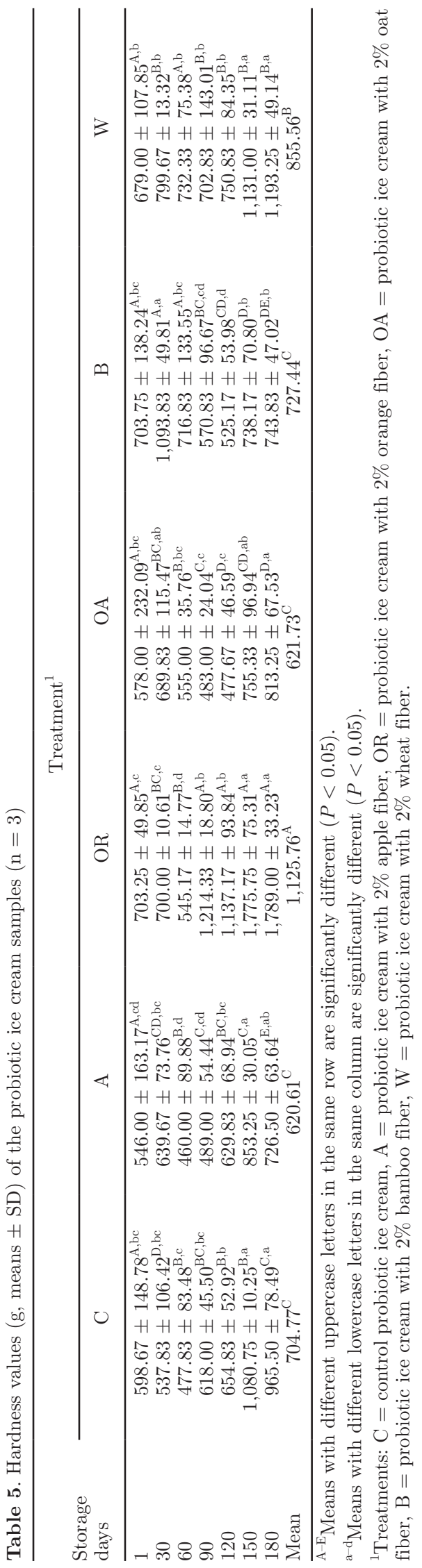

cant increase in these characteristics (Soukoulis et al., 2009). Similarly, hardness was higher in our wheat fiber ice cream than in that containing apple fiber.

Thus, the presence of apple fiber, which caused the highest viscosity in the ice cream mix, did not lead to an ice cream sample with higher firmness. Figuerola et al. (2005) reported that the water retention and swelling capacities of apple fiber concentrates were generally higher than those found in orange fiber concentrates, whereas the maximum compression force measured in orange fiber was higher than that of apple fiber. Similarly, Staffolo et al. (2004) reported that utilization of $1.3 \%$ apple fiber in yogurt manufacture decreased the maximum compression force compared with the control sample, whereas the consistency coefficient and apparent viscosity increased.

\section{Melting Rate}

The melting properties of the probiotic ice cream samples are given in Table 6 . The highest melted weight was found in the control ice cream throughout $180 \mathrm{~d}$ of storage $(P<0.05)$. Melting rate is usually a function of fat structure formation and the rheological properties of ice cream (Marshall et al., 2003). The high melting values of the control and oat fiber ice creams could be related to their rheological properties - they showed the lowest values for viscosity and consistency index. In addition, a low overrun value may have been important in the high melting rate of the control ice cream, as air cells are thought to act as an insulator in ice cream structure (Marshall et al., 2003).

The ice creams with orange or apple fiber added showed the lowest melting values during storage. Muse and Hartel (2004) found that melting rate increases as the level of fat destabilization diminishes, the consistency coefficient decreases, and the ice crystal size increases. Therefore, the higher consistency index and viscosity of ice creams containing orange and apple fiber compared with the other samples may have been responsible for their reduced melted weight. Crizel et al. (2014) reported no significant differences $(P>0.05)$ between ice cream with $1.5 \%$ orange fiber added and control ice cream.

In contrast, melted weight was lower in the wheat fiber ice cream than in the control sample throughout the storage period. In addition, the wheat fiber sample melted less than the ice creams containing oat or bamboo fibers on some storage days. This could be attributed to the higher hardness value of the wheat fiber ice cream compared with samples with oat or bamboo fiber. The melting rate of ice cream has previously been found to be inversely correlated with sample hardness (El-Nagar et al., 2002; Akalın et al., 2008). The melted 
Table 6. Weight (g, means $\pm \mathrm{SD})$ of melted ice cream during storage $(\mathrm{n}=3)$

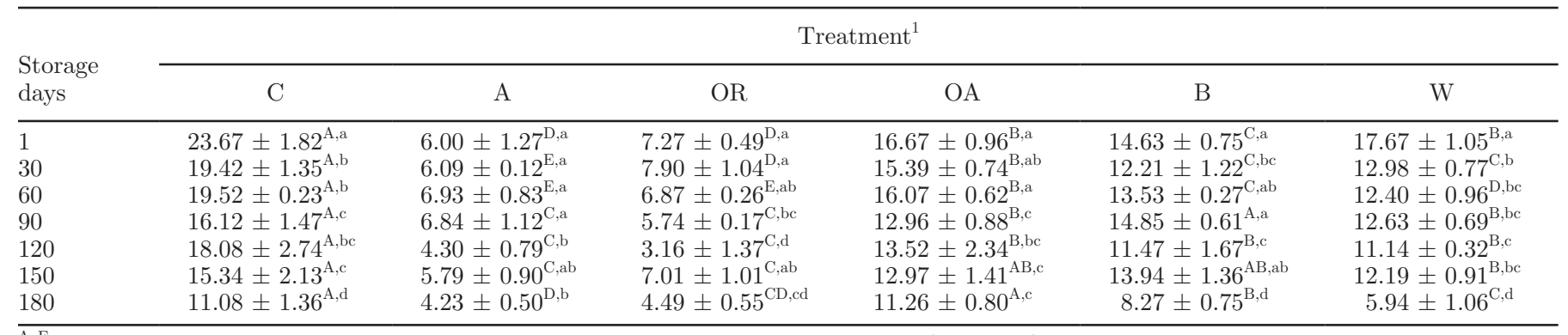

$\overline{\mathrm{A}-\mathrm{E}}$ Means with different uppercase letters in the same row are significantly different $(P<0.05)$.

${ }^{\mathrm{a}-\mathrm{d}}$ Means with different lowercase letters in the same column are significantly different $(P<0.05)$.

${ }^{1}$ Treatments: $\mathrm{C}=$ control probiotic ice cream, $\mathrm{A}=$ probiotic ice cream with $2 \%$ apple fiber, OR $=$ probiotic ice cream with $2 \%$ orange fiber, $\mathrm{OA}=$ probiotic ice cream with $2 \%$ oat fiber, $\mathrm{B}=$ probiotic ice cream with $2 \%$ bamboo fiber, $\mathrm{W}=$ probiotic ice cream with $2 \%$ wheat fiber.

amount of ice cream significantly decreased $(P<0.05)$ in all samples at the end of storage time compared with d 1 of storage. Akalın and Erişir (2008) also detected a decrease in the melting rate of ice cream samples as storage time increased.

\section{Sensory Characteristics}

Taste-flavor, texture, and color-appearance properties of ice cream samples were evaluated as sensory characteristics, as shown in Table 7. In terms of taste-flavor, we found no significant differences $(P>0.05)$ between the control and the experimental ice creams enriched with wheat, oat, or bamboo fibers during storage or among all probiotic ice cream samples on d 60, 120, and 150 of storage. The ice cream samples prepared with apple and orange fibers had lower taste-flavor scores on other storage days. This could be because the orange fiber ice cream had the highest titratable acidity value of all samples. In addition, the panelists perceived an astringent taste-flavor in the orange fiber samples, especially after d 60. Accordingly, taste-flavor scores decreased to $<6$ after that storage day. Crizel et al. (2014) also found that an ice cream sample supplemented with $1.5 \%$ orange fiber had a lower flavor score than the control sample. Moreover, in the present study, the taste-flavor property did not change $(P>$ $0.05)$ throughout $180 \mathrm{~d}$ of storage in any sample except apple fiber ice cream, which showed a sharp decrease in taste-flavor score at the end of storage.

Generally, the type of ice cream and storage time did not significantly $(P>0.05)$ affect the texture characteristic of the samples, similar to the findings of Boff et al. (2013) and Crizel et al. (2014).

All types of ice cream showed similar scores with respect to color-appearance on d 30,120, and 180 of storage $(P>0.05)$. In contrast, the lowest scores were given to samples supplemented with apple fiber $(P<$ $0.05)$ on other days of storage, which can be attributed to the fact that the apple fiber samples had the lowest $\mathrm{L}^{*}$ and highest $\mathrm{a}^{*}$ values.

\section{Survival of Probiotic Bacteria}

Table 8 shows changes in the counts of Lb. acidophilus and B. lactis in ice cream samples throughout $180 \mathrm{~d}$ of storage. The viable counts of $L b$. acidophilus ranged between 6.60 and $7.58 \mathrm{log} \mathrm{cfu} / \mathrm{g}$ in the samples. Although slight fluctuations were seen throughout storage, viable counts decreased in all samples at the end of storage compared with the beginning $(P<0.05)$. The highest count of $L b$. acidophilus throughout storage was obtained in the control followed by the wheat fiber sample. In addition, ice creams fortified with apple and wheat fibers provided counts similar to those of control samples on d 1,30,60, and 90 of storage. Charalampopoulos et al. (2003) reported that wheat extract had a significant protective effect on the viability of $L b$. acidophilus under acidic conditions, and do Espírito Santo et al. (2012) reported that apple fiber increased the viability of $L b$. acidophilus and B. lactis in yogurt.

Viable counts of B. lactis in the samples ranged from 5.15 to $7.10 \log \mathrm{cfu} / \mathrm{g}$ throughout $180 \mathrm{~d}$ of storage (Table 8 ). The highest counts were in control samples, except on d 120 of storage, when the best viability was found in the wheat fiber ice cream. In addition, ice creams fortified with wheat fiber generally had higher viable counts of $B$. lactis than other fiber-added samples ( $P$ $<0.05)$.

In the present study, the control ice cream had the highest viable count of probiotic bacteria, which may have been caused by its low overrun level. In addition, Lb. acidophilus survived better than B. lactis in ice cream over $180 \mathrm{~d}$. However, the minimum effective therapeutic dose, which should exceed $6 \mathrm{log} \mathrm{cfu} / \mathrm{g}$ in a probiotic product (Akalın and Erişir, 2008), was reached by d 150 in all treatments except orange and bamboo fiber samples. The lowest counts were enumerated in 
Table 7. Taste-flavor, texture, and color-appearance scores (means $\pm \mathrm{SD})$ of probiotic ice cream samples during storage $(\mathrm{n}=3)$

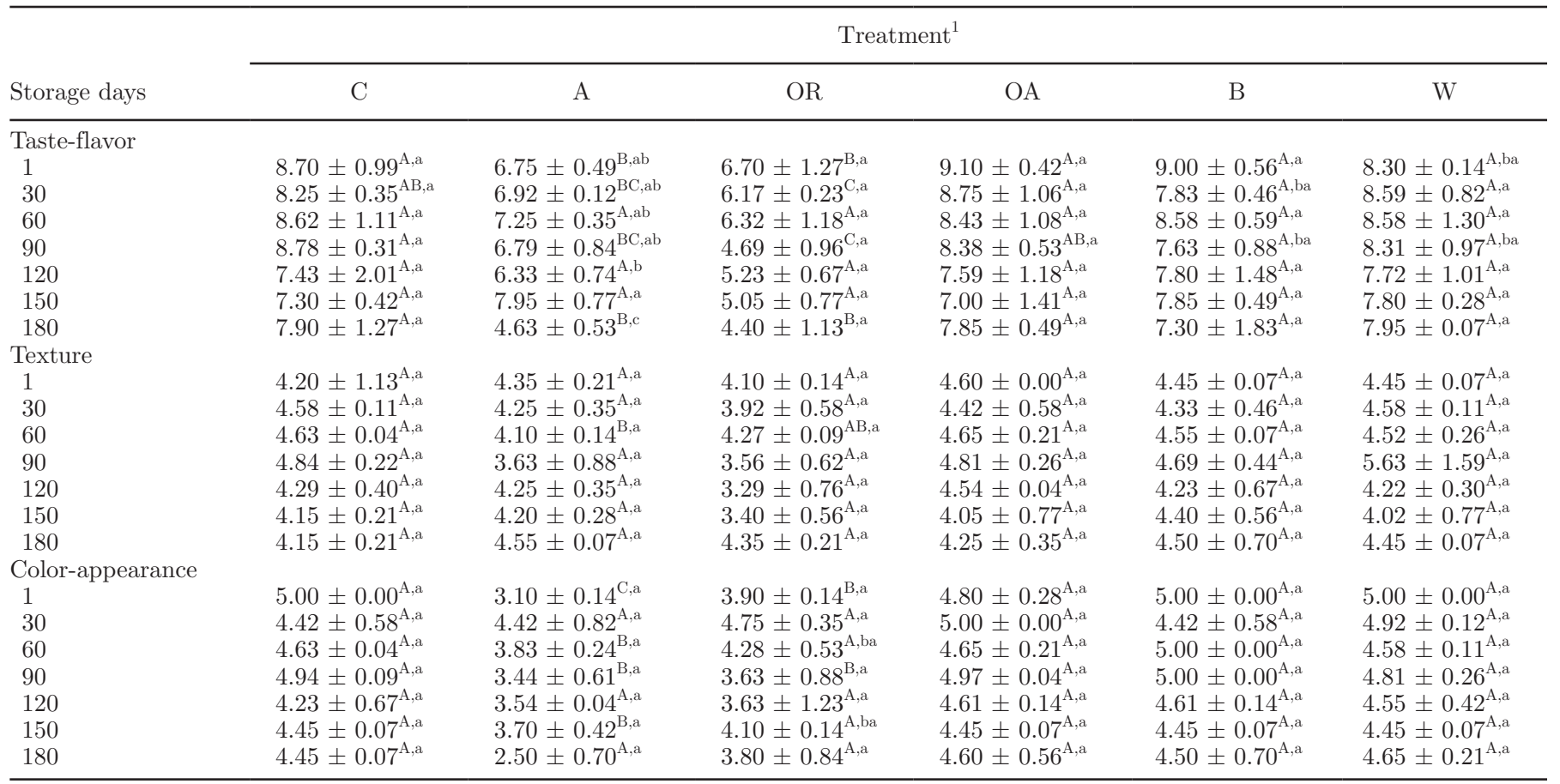

${ }^{\mathrm{A}-\mathrm{C}}$ Means with different uppercase letters in the same row are significantly different $(P<0.05)$.

${ }^{\mathrm{a}-\mathrm{c}}$ Means with different lowercase letters in the same column are significantly different $(P<0.05)$.

${ }^{1}$ Treatments: $\mathrm{C}=$ control probiotic ice cream, $\mathrm{A}=$ probiotic ice cream with $2 \%$ apple fiber, OR $=$ probiotic ice cream with $2 \%$ orange fiber, $\mathrm{OA}=$ probiotic ice cream with $2 \%$ oat fiber, $\mathrm{B}=$ probiotic ice cream with $2 \%$ bamboo fiber, $\mathrm{W}=$ probiotic ice cream with $2 \%$ wheat fiber.

orange fiber samples at the end of storage $(P<0.05)$. This reduction in $B$. lactis may have been caused by the high acidity of the orange fiber samples as well as the presence of inhibitory compounds such as antibacterial polyphenolics (e.g., hesperidin) in orange fiber (Lopez et al., 2007; Kesenkaş, 2010).

Table 8. Viable counts (log cfu/g; means $\pm \mathrm{SD})$ of probiotic bacteria in probiotic ice creams $(\mathrm{n}=3)$

\begin{tabular}{|c|c|c|c|c|c|c|}
\hline Species and storage days & \multicolumn{6}{|c|}{ Treatment $^{1}$} \\
\hline \multicolumn{7}{|l|}{ Lactobacillus acidophilus } \\
\hline 30 & $7.58 \pm 0.03^{\mathrm{A}, \mathrm{a}}$ & $7.28 \pm 0.02^{\mathrm{C}, \mathrm{b}}$ & $6.95 \pm 0.04^{\mathrm{E}, \mathrm{b}}$ & $7.30 \pm 0.00^{\mathrm{C}, \mathrm{b}}$ & $7.18 \pm 0.03^{\mathrm{D}, \mathrm{b}}$ & $7.47 \pm 0.02^{\mathrm{B}, \mathrm{ab}}$ \\
\hline 60 & $7.22 \pm 0.04^{\mathrm{A}, \mathrm{c}}$ & $7.20 \pm 0.02^{\mathrm{A}, \mathrm{b}}$ & $6.79 \pm 0.08^{\mathrm{C}, \mathrm{c}}$ & $7.02 \pm 0.03^{\mathrm{B}, \mathrm{d}}$ & $6.72 \pm 0.08^{\mathrm{C}, \mathrm{c}}$ & $7.25 \pm 0.03^{\mathrm{A}, \mathrm{c}}$ \\
\hline 90 & $7.52 \pm 0.02^{\mathrm{A}, \mathrm{a}}$ & $7.51 \pm 0.04^{\mathrm{A}, \mathrm{a}}$ & $7.09 \pm 0.05^{\mathrm{C}, \mathrm{a}}$ & $7.37 \pm 0.02^{\mathrm{B}, \mathrm{a}}$ & $7.14 \pm 0.05^{\mathrm{C}, \mathrm{b}}$ & $7.55 \pm 0.09^{\mathrm{A}, \mathrm{a}}$ \\
\hline 180 & $7.04 \pm 0.04^{\mathrm{A}, \mathrm{d}}$ & $7.06 \pm 0.06^{\mathrm{A}, \mathrm{c}}$ & $6.89 \pm 0.06^{\mathrm{B}, \mathrm{bc}}$ & $7.09 \pm 0.02^{\mathrm{A}, \mathrm{c}}$ & $6.65 \pm 0.11^{\mathrm{C}, \mathrm{c}}$ & $6.98 \pm 0.07^{\mathrm{AB}, \mathrm{d}}$ \\
\hline \multicolumn{7}{|l|}{ Bifidobacterium lactis } \\
\hline 1 & $6.74 \pm 0.11^{\mathrm{AB}, \mathrm{bc}}$ & $6.77 \pm 0.05^{\mathrm{A}, \mathrm{a}}$ & $6.48 \pm 0.03^{\mathrm{C}, \mathrm{a}}$ & $6.74 \pm 0.03^{\mathrm{AB}, \mathrm{a}}$ & $6.50 \pm 0.07^{\mathrm{C}, \mathrm{a}}$ & $6.64 \pm 0.04^{\mathrm{B}, \mathrm{b}}$ \\
\hline 30 & $7.10 \pm 0.00^{\mathrm{A}, \mathrm{a}}$ & $6.77 \pm 0.03^{\mathrm{C}, \mathrm{a}}$ & $6.26 \pm 0.01^{\mathrm{E}, \mathrm{b}}$ & $6.71 \pm 0.04^{\mathrm{C}, \mathrm{a}}$ & $6.44 \pm 0.06^{\mathrm{D}, \mathrm{a}}$ & $6.87 \pm 0.06^{\mathrm{B}, \mathrm{a}}$ \\
\hline 60 & $6.82 \pm 0.06^{\mathrm{A}, \mathrm{b}}$ & $6.64 \pm 0.02^{\mathrm{B}, \mathrm{b}}$ & $6.15 \pm 0.06^{\mathrm{D}, \mathrm{c}}$ & $6.44 \pm 0.04^{\mathrm{C}, \mathrm{b}}$ & $5.84 \pm 0.02^{\mathrm{E}, \mathrm{b}}$ & $6.71 \pm 0.00^{\mathrm{B}, \mathrm{b}}$ \\
\hline 90 & $6.82 \pm 0.06^{\mathrm{A}, \mathrm{b}}$ & $6.64 \pm 0.02^{\mathrm{B}, \mathrm{b}}$ & $6.15 \pm 0.06^{\mathrm{D}, \mathrm{c}}$ & $6.44 \pm 0.04^{\mathrm{C}, \mathrm{b}}$ & $5.84 \pm 0.02^{\mathrm{E}, \mathrm{b}}$ & $6.71 \pm 0.00^{\mathrm{B}, \mathrm{b}}$ \\
\hline 120 & $6.67 \pm 0.06^{\mathrm{B}, \mathrm{c}}$ & $6.02 \pm 0.08^{\mathrm{D}, \mathrm{d}}$ & $5.97 \pm 0.06^{\mathrm{D}, \mathrm{b}}$ & $6.49 \pm 0.01^{\mathrm{C}, \mathrm{b}}$ & $5.80 \pm 0.08^{\mathrm{E}, \mathrm{b}}$ & $6.99 \pm 0.10^{\mathrm{A}, \mathrm{a}}$ \\
\hline
\end{tabular}

\footnotetext{
${ }^{\mathrm{A}-\mathrm{E}}$ Means with different uppercase letters in the same row are significantly different $(P<0.05)$.

${ }^{\mathrm{a}-\mathrm{f}}$ Means with different lowercase letters in the same column are significantly different $(P<0.05)$.

${ }^{1}$ Treatments: $\mathrm{C}=$ control probiotic ice cream, $\mathrm{A}=$ probiotic ice cream with $2 \%$ apple fiber, OR $=$ probiotic ice cream with $2 \%$ orange fiber, $\mathrm{OA}=$ probiotic ice cream with $2 \%$ oat fiber, $\mathrm{B}=$ probiotic ice cream with $2 \%$ bamboo fiber, $\mathrm{W}=$ probiotic ice cream with $2 \%$ wheat fiber.
} 


\section{CONCLUSIONS}

The addition of orange and apple fibers into ice cream mixes yielded greater improvement in rheological properties and melting resistance compared with control and other experimental samples. However, the viability of $B$. lactis and taste-flavor scores were lower in samples with orange fiber. In the manufacture of probiotic ice cream, wheat fiber has potential to improve rheological and textural characteristics, while maintaining sensory properties and probiotic viability.

\section{ACKNOWLEDGMENTS}

This work was financially supported by Ege University Faculty of Agriculture Scientific Research Foundation (Izmir, Turkey).

\section{REFERENCES}

Akalın, A. S., and D. Erişir. 2008. Effects of inulin and oligofructose on the rheological characteristics and probiotic culture survival in low-fat probiotic ice cream. J. Food Sci. 73:M184-M188.

Akalın, A. S., C. Karagözlü, and G. Ünal. 2008. Rheological properties of reduced-fat and low-fat ice cream containing whey protein isolate and inulin. Eur. Food Res. Technol. 227:889-895.

BahramParvar, M., and M. M. Tehrani. 2011. Application and functions of stabilizers in ice cream. Food Rev. Int. 27:389-407.

BahramParvar, M., and H. D. Goff. 2013. Basil seed gum as a novel stabilizer for structure formation and reduction of ice recrystallization in ice cream. Dairy Sci. Technol. 93:273-285.

Boff, C. C., T. M. Crizel, R. R. Araujo, A. O. Rios, and S. H. Flores. 2013. Development of chocolate ice cream using orange peel fibre as fat replacer. Cienc. Rural 43:1892-1897.

Brookfield Engineering Laboratories. 2014. Food and beverage applications-Butter and margarine. Accessed Jun. 19, 2014. http://www .brookfieldengineering.com/applications/texture-applications/ food-and-beverage/butter-and-margarine.

Charalampopoulos, D., S. S. Pandiella, and C. Webb. 2003. Evaluation of the effect of malt, wheat and barley extracts on the viability of potentially probiotic lactic acid bacteria under acidic conditions. Int. J. Food Microbiol. 82:133-141.

Cody, T. L., A. Olabi, A. G. Petingell, P. S. Tong, and J. H. Walker. 2007. Evaluation of rice flour for use in vanilla ice cream. J. Dairy Sci. 90:4575-4585.

Crizel, T. M., R. R. Araujo, A. O. Rios, R. Rech, and S. H. Flores. 2014. Orange fibre as a novel fat replacer in lemon ice cream. Food Sci. Technol. (Campinas) 34:332-340.

Cruz, A. G., A. E. C. Antunes, A. L. O. P. Sousa, J. A. F. Faria, and S. M. I. Saad. 2009. Ice cream as a probiotic food carrier. Food Res. Int. 42:1233-1239.

Damian, C. 2013. Influence of dietary fibre addition on some properties of yoghurt. Versita 24:17-20.

Dervisoglu, M., and F. Yazıcı. 2006. The effect of citrus fibre on the physical, chemical and sensory properties of ice cream. Food Sci. Technol. Int. 12:159-164.
Di Criscio, T., A. Fratianni, R. Mignogna, R. Cinquanta, R. Coppola, E. Sorrentino, and G. Panfili. 2010. Production of functional probiotic, prebiotic and synbotic ice creams. J. Dairy Sci. 93:4555-4564.

Dimitreli, G., E. A. Gregoriou, G. Kalantzidis, and K. D. Antoniou. 2013. Rheological properties of kefir as affected by heat treatment and whey protein addition. J. Texture Stud. 44:418-423.

do Espírito Santo, A. P. E., N. S. Cartolano, T. F. Silva, F. A. S. M. Soares, L. A. Gioielli, P. Perego, A. Converti, and M. N. Oliveira. 2012. Fibres from fruit by-products enhance probiotic viability and fatty acid profile and increase CLA content in yoghurts. Int. J. Food Microbiol. 154:135-144.

El-Nagar, G., G. Clowes, C. M. Tudorica, V. Kuri, and C. S. Brennan. 2002. Rheological quality and stability of yog-ice cream with added inulin. Int. J. Dairy Technol. 55:89-93.

Figuerola, F., M. L. Hurtado, A. M. Estevez, I. Chiffelle, and F. Asenjo. 2005. Fibre concentrates from apple pomace and citrus peel as potential fibre sources for food enrichment. Food Chem. 91:395-401.

Homayouni, A., A. Azizi, M. R. Ehsani, M. S. Yarmand, and S. H. Razavi. 2008. Effect of microencapsulation and resistant starch on the probiotic survival and sensory properties of synbiotic ice cream. Food Chem. 111:50-55.

Kesenkaş, H. 2010. Effect of using different probiotic cultures on properties of Torba (strained) yoghurt. Mljekarstvo 60:19-29.

Lopez, J. F., M. V. Martos, E. Sendra, E. S. Barbera, C. Navarro, and J. A. P. Alvarez. 2007. Orange fibre as potential functional ingredient for dry-cured sausages. Eur. Food Res. Technol. 226:1-6.

Marshall, R. T., H. D. Goff, and R. W. Hartel. 2003. Chapters 2, 5, 6, and 13 in Ice Cream. 6th ed. Kluwer Academic/Plenum Publishers, New York, NY.

Muse, M. R., and R. W. Hartel. 2004. Ice cream structural elements that affect melting rate and hardness. J. Dairy Sci. 87:1-10.

Pavlovich-Abril, A., O. Rouzaud-Sández, P. Torres, and R. M. RoblesSánchez. 2012. Cereal bran and wholegrain as a source of dietary fibre: Technological and health aspects. Int. J. Food Sci. Nutr. 63:882-892.

Riener, J., F. Noci, D. A. Cronin, D. J. Morgan, and J. G. Lyng. 2010. A comparison of selected quality characteristics of yoghurts prepared from thermosonicated and conventionally heated milks. Food Chem. 119:1108-1113.

Rodehutscord, M., C. Rückert, H. P. Maurer, H. Schenkel, W. Schipprack, K. E. Bach Knudsen, M. Schollenberger, M. Laux, M. Eklund, W. Siegert, and R. Mosenthin. 2016. Variation in chemical composition and physical characteristics of cereal grains from different genotypes. Arch. Anim. Nutr. 70:87-107.

Sagdic, O., I. Ozturk, H. Cankurt, and F. Tornuk. 2011. Interaction between some phenolic compounds and probiotic bacterium in functional ice cream production. Food Bioproc. Techol. 5:2964-2971.

Sah, B. N. P., T. Vasiljevic, S. McKechnie, and O. N. Donkor. 2016. Physicochemical, textural and rheological properties of probiotic yoghurt fortified with fibre-rich pineapple peel powder during refrigerated storage. Lebenson. Wiss. Technol. 65:978-986.

Soukoulis, C., D. Lebesi, and C. Tzia. 2009. Enrichment of ice cream with dietary fibre: Effects on rheological properties, ice crystallization and glass transition phenomena. Food Chem. 115:665-671.

Staffolo, M. D., N. Bertola, M. Martino, and A. Bevilacqua. 2004. Influence of dietary fibre addition on sensory and rheological properties of yogurt. Int. Dairy J. 14:263-268.

Tharmaraj, N., and N. P. Shah. 2003. Selective enumeration of Lactobacillus delbrueckii ssp. bulgaricus, Streptococcus thermophilus, Lactobacillus acidophilus, bifidobacteria, Lactobacillus casei, Lactobacillus rhamnosus and propionibacteria. J. Dairy Sci. 86:22882296. 